\title{
MISINFORMATION RELATED TO COVID-19 IN INDONESIA
}

\author{
Kesalahan Informasi COVID-19 di Indonesia \\ Narila Mutia Nasir ${ }^{1,2}$, Baequni ${ }^{1,2},{ }^{*}$ Mochamad lqbal Nurmansyah ${ }^{1,2}$ \\ ${ }^{1}$ Department of Public Health, Faculty of Health Science, Syarif Hidayatullah Jakarta State Islamic University, \\ Indonesia \\ ${ }^{2}$ Indonesian Public Health Association (IAKMI) for Special Capital Region of Jakarta, Indonesia \\ ${ }^{*}$ Correspondence: iqbalnurmansyah@uinjkt.ac.id
}

\begin{abstract}
Background: An increase in COVID-19 cases has been accompanied by an increase in public misinformation around basic coronavirus facts, its transmission, and its prevention.

Aims: This study describes public knowledge of COVID-19 misinformation in Indonesia.

Methods: This study was a cross-sectional study using online questionnaires for data collection from 4 April to 11 April 2020. The questionnaires consisted of two parts regarding demographic characteristics and knowledge of misinformation. The sample in this study was 530 respondents. Descriptive analysis was used for data analysis.

Results: The majority of respondents were below 25 years old $(n=342,64.5 \%)$ and had graduated from junior/senior high school education $(n=277,52.3 \%)$. Of the respondents, $13.2 \%$ believed the COVID-19 would stop in Indonesia's climate, while $27.7 \%$ stated that COVID-19 is a biological weapon deliberately created by another country. Meanwhile, $19.6 \%$ believed that gargling with salt water or vinegar can kill the COVID-19 virus. Conclusion: A group of people still did not understand misinformation regarding COVID-19. Various efforts are needed to align community understanding of COVID-19 prevention and to provide accurate information.
\end{abstract}

Keywords: COVID-19, misinformation, prevention measures, SARC-CoV-2.

\section{ABSTRAK}

Latar Belakang: Meningkatnya kasus COVID-19 diiringi dengan meningkatnya misinformasi publik seputar fakta dasar virus corona, penularan dan pencegahannya.

Tujuan: Penelitian ini bertujuan untuk menggambarkan pengetahuan publik terkait misinformasi COVID-19 di Indonesia.

Metode: Penelitian ini merupakan studi potong lintang menggunakan formulir daring untuk pengumpulan data. Pengumpulan data dilakukan pada 4 hingga 11 April 2020. Kuesioner penelitian terdiri dari dua bagian terkait karakteristik demografi dan pengetahuan terkait misinformasi. Sampel dalam penelitian ini berjumlah 530 responden. Analisis deskriptif digunakan untuk analisis data.

Hasil: Mayoritas responden berusia kurang dari 25 tahun $(n=342,64,5 \%)$ dan lulus dari tingkat pendidikan sekolah menengah pertama/atas ( $n=277,52,3 \%$ ). Terdapat $13,2 \%$ responden yang masih beranggapan bahwa virus SARS-CoV-2 tidak bisa hidup di iklim Indonesia, sedangkan 27,7\% menyatakan bahwa virus tersebut merupakan senjata biologis yang sengaja dibuat oleh suatu negara. Sementara itu, 19,6\% responden masih percaya bahwa berkumur dengan air garam atau cuka dapat membunuh virus.

Kesimpulan: Sekelompok orang masih tidak mengetahui kesalahan informasi terkait pencegahan COVID-19. Berbagai upaya perlu diambil untuk meluruskan pemahaman masyarakat terkait pencegahan COVID-19, sehingga masyarakat memiliki pemahaman yang benar .

Kata kunci: COVID-19, misinformasi, langkah pencegahan, SARS-CoV-2.

\section{INTRODUCTION}

The World Health Organization (WHO) announced the coronavirus (COVID-19) pandemic on March 11 $1^{\text {th }}, 2020$ (World Health Organization, 2020f). This infection is caused by Severe Acute
Respiratory Syndrome Coronavirus 2 (SARS-CoV-2). A study stated that people infected by SARS-CoV-2 exhibit such symptoms as dry cough, fatigue, fever, and dyspnea (Wu et al., 2020). The virus is transmitted from person to person through 
respiratory droplets and contact routes (World Health Organization, 2020e).

As of April $24^{\text {th }} 2020$, a total of $2,626,321$ people globally had been confirmed as testing positive for the virus (World Health Organization, 2020d). The number of COVID-19 cases in Indonesia also continued to increase. On May $7^{\text {th }}$, 2020, the number of confirmed cases reached 12,776. The COVID-19 pandemic has affected not only people's health, but also other aspects of life. The United Nations University World Institute for Development Economics Research estimated that COVID-19 has become one of the challenges to ending poverty as one of the United Nations Sustainable Development Goals. Although poverty has decreased since 1990, it has dramatically surged since the COVID-19 pandemic (Sumner, Hoy, and Ortiz-juarez, 2020). Moreover, the United Nations Development Program has predicted that COVID-19 supresses economies and exacerbates inequality (United Nations Development Programme, 2020).

Combating the COVID-19 pandemic has become the responsibility of health workers and communities since they are on the frontline in detecting and managing epidemics (World Health Organization, 2018). WHO recommends basic protective measures against COVID-19 including frequent handwashing with soap; social (physical) distancing; not touching the eyes, nose, and mouth; and respiratory hygiene etiquette (World Health Organization, 2020b). Certainly, appropriate knowledge should be provided to each person so they may perform preventive measures correctly. The social ecological model, as defined by McLeroy, identifies knowledge as one of the intrapersonal factors that determine health behaviors (Sutton, 2014).

Unfortunately, the increase in the number of COVID-19 cases is consistent with the spread of an infodemic. An infodemic involves an excessive amount of information, some of which is accurate while some is not, and thus people find it difficult to identify trustworthy, reliable sources as needed (World Health Organization, 2020c). The WHO has identified several themes of misinformation related to COVID-19 such as its cause and origins, its symptoms and transmission patterns, available treatments, and the effectiveness and impact of interventions by health authorities or other institutions (World Health Organization, 2020c).

Misinformation is a false healthrelated claim of fact that lacks scientific evidence (Chou, Oh, and Klein, 2018). It is also defined as information that is incorrect possibly by accident (Scheufele and Krause, 2019). Misinformation is different from disinformation. Disinformation does not always spread false information; it can also be accurate information that has an intended harmful effect on a target (Volkin, 2020).

Anxiety and uncertainty about the pandemic can create a suitable environment for misinformation (Thulin, 2020). Misinformation regarding COVID-19 could put people at risk as it may give them a false sense of security (Simon Fraser University, 2020). The spread of COVID-19 misinformation has been rising globally (Mian and Khan, 2020). The public health crisis due to the disease has stimulated misinformation. Moreover, evidence suggests that untruths spread more easily than truths (Vosoughi, Roy, and Aral, 2018).

COVID-19 misinformation has also occurred in Indonesia, spreading massively on social media. This is not surprising because most Indonesians are social media users. With 120 million Facebook users, Indonesia is ranked third among Facebook users, behind only India and United States in January 2020 (Statista, 2020). 
Hence, the Indonesian government has identified and taken action against misinformation through a hoax-buster section on their official website. There are several issues regarding misinformation, such as government policies of COVID-19 countermeasures, various conditions of several regions after the COVID-19 impact, and other several issues (COVID-19 Response Acceleration Task Force, 2020c). Although the government has responded to tackle false information, it still spreads throughout the community.

Nonetheless, research about COVID19 misinformation among Indonesians is rare. Research on this topic is required to give insights to the government or other parties concerned with health education. With such data, they can design suitable material for prevention issues, and thus the public can gain accurate information. Therefore, this study aimed to describe public knowledge of COVID-19 misinformation among Indonesian citizens.

\section{METHODS}

This study was cross-sectional, using online questionnaires for data collection from 4 April to 11 April 2020. The variable assessed was respondents' knowledge of COVID-19 misinformation. Misinformation in this study was defined as a false claim of fact due to lack of scientific evidence (Chou, Oh, and Klein, 2018). A respondent was considered informed when they had correct knowledge of the issues. The respondents were categorized as misinformed when they believed in incorrect or counterfactual claims. Moreover, they were considered uninformed when they were simply unaware of the facts or did not have a factual belief (Gidengil et al., 2004; Scheufele and Krause, 2019).

The online questionnaire consisted of two sections: demographic characteristics of the respondents (sex, age, level of education, and occupation) and public knowledge of 11 misinformation topics related to COVID-19 basic facts, its modes of transmission, and prevention measures. Misinformation topics were developed by selecting several current issues of COVID19 misinformation from the "Myth Busters" section on World Health Organization's website and the "Hoax Buster" section on the COVID-19 Response Acceleration Task Force's website (COVID-19 Response Acceleration Task Force, 2020c; World Health Organization, 2020a).

Eleven topics were chosen from several misinformation issues applicable only to the Indonesian context. For example, the public was misinformed about COVID-19 transmission through houseflies (this study assumed that such a topic did not exist among Indonesians). Several topics were irrelevant to the health aspect, such as political issues. Respondents were asked to answer "yes," "no," and "do not know" for each piece of misinformation presented in the online questionnaire.

The questionnaire was then measured for reliability by calculating Cronbach's $\alpha$. The Cronbach's $\alpha$ for the questionnaire was 0.704 . The $\alpha$-value of 0.70 was considered sufficient for reliability or internal consistency of an instrument (Taber, 2018).

Before the respondents filled out the questionnaire, they were informed about the aim of the study, how to answer questions, and other information related to this research. Respondents who agreed to join the study would click the "next" button to continue to fill out the questionnaire.

The minimum sample was calculated for cross-sectional studies/surveys (Charan and Biswas, 2013). The sample was obtained with the precision of $5 \%$, and the expected proportion in population based on the previous study was $23 \%$ with a minimum of 237 samples (Berman, 2020). Inclusion criteria of the respondents included age and location. The 
respondents were a minimum of 17 years old, and a total of 530 respondents lived in Jakarta and outside. The sample was chosen by using a consecutive sampling method in which the respondents could be recruited per the inclusion criteria (Setia, 2016). The survey invitation was sent via social media such as WhatsApp and Instagram. A descriptive statistical method was employed to present the results of the study.

\section{RESULTS AND DISCUSSION}

Table 1 illustrates the respondents' demographic characteristics. Most of the respondents were female ( $n=404,76.3 \%)$ and in the age group of $\leq 25$ years old $(n=$ $342,64.5 \%)$. Around $52.3 \% \quad(n=277)$ graduated from secondary high school, and $70 \%$ of them resided in Jakarta $(n=371)$.

In Table 2, COVID-19 misinformation is explained. As many as $13.2 \%$ expressed that the SARS-CoV-2 virus cannot live in the Indonesian climate, while $17.2 \%$ of them were not sure about that issue. Furthermore, $27.7 \%$ of them stated that the SARS-CoV-2 virus was a biological weapon of a particular country. Moreover, $36.2 \%$ of them believed that exposing money or goods to the sun for about 30 minutes can kill the virus. There were $19.6 \%$ of respondents who thought that gargling with salt water or vinegar can kill the virus, while $3.47 \%$ were not aware of that issue. The last issue is that $12.1 \%$ of the respondents did not know whether or not spraying disinfectant on the body is safe or not.

There was a growing assumption that high temperature and humidity will reduce the virus and its ability to reproduce and spread. Some people still believe that COVID-19 could not survive in a tropical country like Indonesia (COVID-19 Response Acceleration Task Force, 2020a). In fact, WHO stated that COVID-19 virus can spread in hot and humid climates.

Besides, the SARS-CoV-2 virus has infected more than 21,000 people in Indonesia by May 2020 (COVID-19 Response Acceleration Task Force, 2020b). In spite of temperature and humidity's effect on viral growth, a preliminary study found a significant correlation between temperature average and the incidence rate of COVID-19 in Jakarta (Tosepu et al., 2020). Another study revealed sunlight exposure was correlated significantly with COVID-19 recovery among patients in Jakarta (Asyary and Veruswati, 2020). Therefore, $13.2 \%$ of respondents were still misinformed, and $17.2 \%$ were still uninformed about that issue.

The idea that the virus is a bioweapon was oppsed by Tom Inglesby, an expert in health security, who said there was no evidence of anything of it being anything other than a naturally occurring virus (Powder, 2020). Moreover, Saputra, a researcher from the Indonesian Institute of Sciences (LIPI), stated that the virus was not a biological weapon because it had no gene similar to other corona viruses such as flu, MERS and SARS 2002 (COVID-19 Response Acceleration Task Force, 2020c). However, the community easily believed information about tips to prevent the infection of the SARS-CoV-2 virus since they were too afraid of viral infection. The results revealed that $27.7 \%$ of respondents were misinformed about this issue.

The results also explained that $17.2 \%$ of the respondents believed the virus could spread through the air. However, from the analysis of 75,465 COVID-19 cases in China, airborne transmission was not reported (Ong et al., 2020). With a such evidence, some respondents were still misinformed about this issue.

Using hand sanitizer is believed to eliminate the virus. As a result, the public bought an excessive amount of hand sanitizers, causing stockout, which, in turn, stimulated fake hand sanitizer producers. A 
previous study pointed out that, when simple handwashing with unmedicated soap and water was undertaken appropriately, it was highly effective in removing influenza virus from hands (Grayson et al., 2009).

Despite physical or social distancing, the best practice to prevent the transmission of the SARS-CoV-2 virus is by maintaining personal hygiene, especially by washing hands with soap frequently after touching surfaces or after coming in from outside. Hand sanitizers are alternatives when it is hard to find water and soap. Improper use of hand sanitizers could cause irritation. Therefore, the $16.4 \%$ of the respondents who believed one must use hand sanitizers for handwashing have been misinformed.

Table 1. Respondents' Demographic Characteristics.

\begin{tabular}{lcc}
\hline & $\mathbf{n = 5 3 0}$ & $\%$ \\
\hline Sex & & 76.3 \\
\hline Female & 404 & 23.8 \\
\hline Male & 126 & 64.5 \\
\hline Age group & 342 & 27.9 \\
\hline 25 & 148 & 7.5 \\
\hline $26-45$ & 40 & 0.2 \\
\hline Education & 1 & 52.3 \\
\hline Primary school & 277 & 9.6 \\
\hline Secondary high school & 51 & 32.8 \\
\hline Diploma & 174 & 5.1 \\
\hline Bachelor degree & 27 & 9.8 \\
\hline Graduate/Postgraduate & & \\
\hline Occupancy & 52 & 24.0 \\
\hline Civil Servant/State-owned corporation & & 2.8 \\
staf/Police/Military & 127 & 46.4 \\
\hline Private sector & 15 & 8.5 \\
\hline Informal sector & 246 & 8.5 \\
\hline Student with health major & 45 & 70.0 \\
\hline Student with non-health major & 45 & 30.0 \\
\hline Housewife & & \\
\hline Domicile & 371 & 159 \\
\hline Jakarta & & \\
\hline Outside Jakarta & & \\
\hline & & \\
\hline & & \\
\hline & & \\
\hline & & \\
\hline
\end{tabular}

Another instance of misinformation found was that gargling with saltwater or vinegar can kill the virus. Gargling with salt water, vinegar, or warm water was asummed to prevent the virus from entering the lungs. Unfortunately, no evidence has, to date, demonstrated this (Mascarenhas, 2020). Even though gargling or drinking hot/warm water mixed with vinegar or salt has long been used by Indonesians as an alternative to relieve influenza or sore throat symptoms, but there is no medical evidence for this method to prevent COVID19 (lka, 2020). Among the respondents, $19.6 \%$ were still uninformed as they agreed with the idea of gargling with salt or vinegar.

Spraying disinfectant all over the body was assumed to kill the virus. The community's perception was that someone who has been sprayed can freely move without physical distancing anymore. However, WHO stated that spraying 
alcohol or chlorine all over the body can be harmful to clothes or mucous membranes (i.e., eyes, mouth) (World Health Organization, 2020b).

The use of disinfectant became massive since people believed it would make them free from the virus. However, they should be informed that people infected by the SARS-CoV-2 virus still had the possibility to transmit the virus although their body may have been sprayed with disinfectant. Inappropriately using disinfectant may be poisonous. Some cases were reported in the United States for using disinfectant during the COVID-19 pandemic (Chang et al., 2020). Moreover, physical or social distancing and good personal hygiene are more important to reducing the potential risk of infection rather than using disinfectant products, some of which did not effectively kill the virus (Hamzelou, 2020). Based on this evidence, $12.1 \%$ of respondents were still misinformed about the use of disinfectant.

Table 2. COVID-19 Misinformation in the Indonesian Community.

\begin{tabular}{|c|c|c|c|}
\hline Statements & Yes n (\%) & No $n(\%)$ & $\begin{array}{c}\text { Do not } \\
\text { know n } \\
(\%)\end{array}$ \\
\hline \multicolumn{4}{|l|}{ COVID-19 Basic Facts } \\
\hline The virus cannot live in the Indonesian climate & 70 (13.2) & $369(69.6)$ & $91(17.2)$ \\
\hline $\begin{array}{l}\text { The virus is a biological weapon made by a certain } \\
\text { country }\end{array}$ & $147(27.7)$ & $155(29.2)$ & $228(43.0)$ \\
\hline \multicolumn{4}{|l|}{ COVID-19 Transmission } \\
\hline The virus is transmitted through the air & $91(17.2)$ & $439(82.8)$ & - \\
\hline $\begin{array}{l}\text { Turmeric makes the body more susceptible to the } \\
\text { virus }\end{array}$ & $26(4.9)$ & $325(61.3)$ & $179(33.8)$ \\
\hline $\begin{array}{l}\text { If we are not strong enough to hold our breath for } \\
10 \text { seconds, then we are suspected of having } \\
\text { contracted the virus }\end{array}$ & $53(10.0)$ & $316(59.6)$ & $161(30.4)$ \\
\hline \multicolumn{4}{|l|}{ Prevention of COVID-19 } \\
\hline $\begin{array}{l}\text { Handwashing with water (no need to use soap) is } \\
\text { enough to prevent the virus }\end{array}$ & $132(24.9)$ & $390(73.6)$ & $8(1.5)$ \\
\hline $\begin{array}{l}\text { Handwashing must involve hand sanitizer (cannot } \\
\text { use soap) to prevent the virus }\end{array}$ & $87(16.4)$ & $430(81.1)$ & $13(2.5)$ \\
\hline Taking chloroquine can prevent the virus & $39(7.4)$ & $295(55.7)$ & $196(37.0)$ \\
\hline $\begin{array}{l}\text { Gargling with salt water or vinegar can eliminate } \\
\text { the virus }\end{array}$ & $104(19.6)$ & $242(45.7)$ & $184(34.7)$ \\
\hline $\begin{array}{l}\text { Exposing money or goods to the sun for about } 30 \\
\text { minutes can eliminate the virus }\end{array}$ & $192(36.2)$ & $152(28.7)$ & $186(35.6)$ \\
\hline $\begin{array}{l}\text { Spraying disinfectant on the body is a safe way to } \\
\text { disinfect surfaces }\end{array}$ & $64(12.1)$ & $423(79.8)$ & $43(8.1)$ \\
\hline
\end{tabular}

There were 225 pieces of COVID-19 misinformation published in English between January and March 2020 (Brennen et al., 2020). That "the virus is not heat-resistant and will halt in a temperature of just 26/27 degrees" is one of the misinformation issues in Indonesia. The rapid spread of misinformation confuses the public, hindering public trust, consensus, and subsequent action to prevent and mitigate COVID-19 measures (Limaye et al., 2020).

This present study revealed that there are groups of people who remained misinformed and uninformed about the COVID-19 and its prevention. Only valid and agile information that could be accessed by all groups can become a defense against rising public panic, financial market hysteria, and unintended 
misunderstandings of the science and epidemiology of SARS-CoV-2 (Garrett, 2020).

Actions should be carried out to increase public awareness of the risks of misinformation, subliminal advertising, and polarization by building an international coalition to increase the state's capacity to prevent, detect, and respond to threats of the infectious disease (Felten and Nelson, 2019). Another strategy to counter misinformation is by swamping fake news with the truth using the counterintuitive approach (Alemanno, 2018). Trustworthy data produced by healthcare researchers could fight against misinformation (Rochwerg et al., 2020).

This study has presented new insights into COVID-19 misinformation in Indonesia, but it also has some limitations. First, this study's is too small to represent the general Indonesian population. Second, the differences in the public's understanding based on the different demographic characteristics could not be analyzed since this study used a descriptive design. Further research with an analytical design needs to be conducted to examine the public's understanding of misinformation among different groups. Third, this study merely described 11 issues of COVID-19 misinformation. Hence, further studies which analyze more COVID-19 misinformation issues need to be performed in the future.

\section{CONCLUSION}

A group of people still remained misinformed and uninformed about COVID19 (its origin, transmission and preventive measures). Public health authorities and other parties concerned about public health education should be more aware of clarifying those misinformation issues, particularly virus transmission and preventive measures. They could use various forms of social media to spread truths to tackle misinformation. Again, even though the public might have been informed several times, education on how to choose accurate information should be intensified. Otherwise, more people will be exposed to a lot of misinformation which can place them at risk of performing wrong protocol and preventive measures.

\section{CONFLICT OF INTEREST}

The authors declare that they have no competing interests.

\section{REFERENCES}

Alemanno, A. (2018) 'How to Counter Fake News? A Taxonomy of Anti-fake News Approaches', European Journal of Risk Regulation, 9(1), pp. 1-5. doi: 10.1017/err.2018.12.

Asyary, A. and Veruswati, M. (2020) 'Sunlight exposure increased Covid19 recovery rates: A study in the central pandemic area of Indonesia', Science of The Total Environment, 729, pp. 1-4. doi: https://doi.org/10.1016/j.scitotenv.20 20.139016.

Brennen, A. J. S. et al. (2020) Types, Sources, and Claims of COVID-19 Misinformation, Research. Available at:

https://reutersinstitute.politics.ox.ac.u $\mathrm{k} /$ types-sources-and-claims-covid-

19-misinformation (Accessed: 24 April 2020).

Charan, J. and Biswas, T. (2013) 'How to calculate sample size for different study designs in medical research?', Indian Journal of Psychological Medicine, 35(2), pp. 121-126. doi: 10.4103/0253-7176.116232.

COVID-19 Response Acceleration Task Force (2020a) Apakah virus COVID19 dapat menular di daerah iklim panas dan lembab, Tanya Jawab. Available

at: 
https://covid19.go.id/tanya-

jawab?search=Apakah virus COVID19 dapat menular di daerah iklim panas dan lembab? (Accessed: 12 June 2020).

COVID-19 Response Acceleration Task Force (2020b) Data Sebaran, Gugus Tugas Percepatan Penanganan COVID-19. Available at: https://covid19.go.id/ (Accessed: 2 May 2020).

COVID-19 Response Acceleration Task Force (2020c) Hoax Buster, Hoax Buster. Available at: https://covid19.go.id/p/hoax-buster (Accessed: 8 May 2020).

Felten, B. Y. C. and Nelson, A. (2019) 'Countering Misinformation With Lessons From Public Health', New Perspectives in Foreign Policy, October 1(18), pp. 52-60.

Garrett, L. (2020) 'COVID-19: the medium is the message', The Lancet. Elsevier Ltd, 395(10228), pp. 942-943. doi: 10.1016/S0140-6736(20)30600-0.

Gidengil, E. et al. (2004) Citizens. Vancouver: UBC Press. doi: $10.1177 / 1354068801007004005$.

Grayson, M. L. et al. (2009) 'Efficacy of Soap and Water and Alcohol-Based Hand-Rub Preparations against Live H1N1 Influenza Virus on the Hands of Human Volunteers', Clinical Infectious Diseases, 48(1), pp. 285291. doi: $10.1086 / 595845$.

Hamzelou, J. (2020) 'Coronavirus spreads', New Scientist, 245(3267)(8), p. 1. doi: 10.1016/s0262-4079(20)301883.

Ika (2020) Saltwater Gargling is not a Way Against Covid-19, Universitas Gadjah Mada. Available

at: https://www.ugm.ac.id/en/news/1935 0-saltwater-gargling-is-not-a-wayagainst-covid-19 (Accessed: 2 May 2020).

Lehmann, U. and Sanders, D. (2007) Community Health Workers: What do we know about them? Geneva. doi: 10.1016/B978-012373960-5.00534-

7.

Limaye, R. J. et al. (2020) 'Comment Building trust while influencing online COVID-19 content in the social media world', The Lancet. The Author(s). Published by Elsevier Ltd. This is an Open Access article under the CC BY-NC-ND 4.0 license, Vol 2(June), pp. e277-e278. doi: 10.1016/S25897500(20)30084-4.

Mascarenhas, A. (2020) Explained: Can gargling with salt water prevent COVID-19 infection?, The Indian Express. Available at: https://www.msn.com/en-in/health/indepth/explained-can-gargling-withsalt-water-prevent-covid-19infection/ar-BB12DbRi (Accessed: 8 May 2020).

Mian, A. and Khan, S. (2020) 'Coronavirus: The spread of misinformation', BMC Medicine, 18(89), pp. 1-2. doi: 10.1186/s12916-020-01556-3.

Ong, S. W. X. et al. (2020) 'Air, Surface Environmental, and Personal Protective Equipment Contamination by Severe Acute Respiratory Syndrome Coronavirus 2 (SARSCoV-2) from a Symptomatic Patient', Journal of the American Medical Association, 323(16), pp. 1610-1612. doi: 10.1001/jama.2020.3227.

Powder, J. (2020) COVID-19 Myths vs. Realities, COVID-19 School Of Public Health Expert Insights. Available at: https://www.jhsph.edu/covid19/articles/coronavirus-facts-vsmyths.html\#tom-inglesby (Accessed: 2 May 2020).

Rochwerg, B. et al. (2020) 'Misinformation During the Coronavirus Disease 2019 Outbreak', Critical Care Explorations, 2(4), pp. 1-6. doi: $10.1097 /$ cce. 0000000000000098 .

Scheufele, D. A. and Krause, N. M. (2019) 'Science audiences, misinformation, 
and fake news', Proceedings of the National Academy of Sciences of the United States of America, 116(16), pp. 7662-7669. doi: $10.1073 /$ pnas.1805871115.

Setia, M. (2016) 'Methodology series module 5: Sampling strategies', Indian Journal of Dermatology, 61(5), pp. 505-509. doi: 10.4103/00195154.190118.

Simon Fraser University (2020) How to tackle medical misinformation during COVID-19, SFU News. Available at: https://www.sfu.ca/sfunews/stories/2 020/04/how-to-tackle-medicalmisinformation-during-covid-19.html (Accessed: 23 May 2020).

Statista (2020) Countries with the most Facebook users 2020, Social Media \& User-Generated Content. Available at:

https://www.statista.com/statistics/26 8136/top-15-countries-based-onnumber-of-facebook-users/ (Accessed: 8 May 2020).

Sumner, A., Hoy, C. and Ortiz-juarez, E. (2020) Estimates of the impact of COVID-19 on global poverty. 2020/43. Helsinki: United Nations University World Institute for Development Economics Research. Available at: https://www.wider.unu.edu/sites/defa ult/files/Publications/Workingpaper/PDF/wp2020-43.pdf.

Sutton, S. (2014) 'Theory of planned behaviour', in Ayers, S. et al. (eds) Cambridge Handbook of Psychology, Health and Medicine, Second Edition. Cambridge. Cambridge: Cambridge University Press, pp. 223-228. doi: 10.1017/CBO9780511543579.049.

Taber, K. S. (2018) 'The Use of Cronbach's Alpha When Developing and Reporting Research Instruments in Science Education', Research in Science Education, 48, pp. 12731296. doi: 10.1007/s11165-016-
9602-2.

Thulin, L. (2020) How to Avoid Misinformation About COVID-19, Smithsonian Magazine. Available at: https://www.smithsonianmag.com/sci ence-nature/how-avoidmisinformation-about-covid-19180974615/ (Accessed: 25 April 2020).

Tosepu, R. et al. (2020) 'Correlation between weather and Covid-19 pandemic in Jakarta, Indonesia', Science of the Total Environment, 725, pp. 1-4. doi: 10.1016/j.scitotenv.2020.138436.

United Nations Development Programme (2020) COVID-19: Looming crisis in developing countries threatens to devastate economies and ramp up inequality. Available at: https://www.undp.org/content/undp/e n/home/news-

centre/news/2020/COVID19_Crisis_i n_developing_countries_threatens_d evastate_economies.html (Accessed: 8 May 2020).

Volkin, S. (2020) Recognizing disinformation during the COVID-19 pandemic, Hub. Available at: https://hub.jhu.edu/2020/05/08/thom as-rid-disinformation-in-covid-19pandemic/ (Accessed: 23 May 2020). Vosoughi, S., Roy, D. and Aral, S. (2018) 'The spread of true and false news online', Science, 359(6380), pp. 1146-1151. doi: 10.1126/science.aap9559.

World Health Organization (2017) WHO report on the global tobacco epidemic, 2017: monitoring tobacco use and prevention policies. Geneva. doi: Licence: CC BY-NC-SA 3.0 IGO.

World Health Organization (2018) Managing epidemics: key facts about major deadly disease. Geneva: World Health Organization.

World Health Organization (2020a) Coronavirus disease (COVID-19) 
advice for the public: Myth busters, World Health Organization. Available at:

https://www.who.int/emergencies/dis eases/novel-coronavirus-

2019/advice-for-public/myth-busters (Accessed: 24 April 2020).

World Health Organization (2020b) Coronavirus disease (COVID-19) advice for the public, World Health Organization. Available at: https://www.who.int/emergencies/dis eases/novel-coronavirus-

2019/advice-for-public (Accessed: 25 April 2020).

World Health Organization (2020c) Coronavirus disease 2019 (COVID19) Situation Report - 86. Geneva. doi: 10.1001/jama.2020.2633.

World Health Organization (2020d) Coronavirus disease 2019 (COVID19) Situation Report - 95, World Health Organization. Geneva. doi: 10.1001/jama.2020.2633.

World Health Organization (2020e) Modes of transmission of virus causing COVID-19: implications for IPC precaution recommendations, World Health Organization. Available at: https://www.who.int/news-

$\mathrm{room} / \mathrm{commentaries/detail/modes-of-}$ transmission-of-virus-causing-covid19-implications-for-ipc-precautionrecommendations (Accessed: 8 May 2020).

World Health Organization (2020f) WHO Timeline - COVID-19, World Health Organization. Available at: https://www.who.int/newsroom/detail/27-04-2020-whotimeline---covid-19 (Accessed: 3 May 2020). 